\title{
ECONOMIC AND RELIGIOUS ATTITUDES OF \\ ENTREPRENEURS IN A VILLAGE INDUSTRY: \\ NOTES ON THE COMMUNITY OF BATUR
}

Kuntowidjojo

Translated by Mitsuo Nakamura*

In the anthropological and sociological writings on Indonesia, there has been a general consensus assigning the responsibility for Islamic reform to the bourgeoisie, especially in the cities. W. F. Wertheim regards the two reformist Moslem organizations Sarekat Islam and Muhammadijah as displaying many bourgeois traits and in turn being supported by the bourgeoisie. Clifford Geertz also sees the religious ethics of a reformist movement in Modjokuto as conforming with the ethics required by the bourgeoisie. ${ }^{2}$ But in a broader perspective, the validity of this generalization has yet to be checked.

In December 1970, I visited the hamlet (dukuh) of Batur, village (kaZurahan) of Tegalredjo, subdistrict (ketjamatan) of Tjeper, district (kabupaten) of Kiaten, Central Java. The visit was made with the intention of gathering data about village (desa) industry. Yet it was primarily economic and religious attitudes of the entrepreneurs in this hamlet that attracted my attention.

\section{Economic Attitudes}

Unlike that of the surrounding agricultural and semi-industrial villages and hamlets, the economic basis of Batur is industry. Here the enterprise of metal casting has a long history and has been linked to agricultural needs. Craftsmen (tukang), ${ }^{3}$ who in the past

* Note from the translator: The original Indonesian version of this paper was presented to the meetings of the 1971 Week of Academic Activities and Graduation Commemorating the fourth Five-Year Period Since the Foundation of the Faculty of Letters and Culture at the University of Gadjah Mada. I would like to express my appreciation to Mr. Tedjo Soesilo, Mr. Ward Keeler, and Professor Sartono Kartodirdjo for their help in translating this article.

1. W. F. Wertheim, Indonesian Society in Transition: A Study of Social Change (Bandung: Sumur Bandung, 1956), especially the chapter entitled, "Religious Reform," pp. 168-198.

2. For example, Clifford Geertz, Peddlers and Princes: Social Change and Economic Modernization in Two Indonesian Towns (Chicago and London: The University of Chicago Press, 1968), which was originally published in 1963.

3. On the subject of tukang, see Geertz, op. cit., pp. 59-70. 
made kedjèn (metal harrows to plow the land), have already developed into entrepreneurs. They now manufacture various kinds of metal products such as pulleys, frying pans, irons, sewing machine legs, weighing scales, weaving machine parts, and factory tools. The development of many factories has given rise to orders for factory tools. The progression from craftsmanship to enterprise has brought with it changes in organizational forms and technology. The craft work which was carried out at home by family members and which produced simple tools for the needs of surrounding villages has already become an enterprise. This business operates as a factory system including wage laborers and manufactures more complicated products for more extensive needs. The technique of casting metal used to be carried out by a fireplace called a besazi which was heated by charcoal. Air was pumped in by means of a lamus (bellows made of cow. skin). The process took from dawn to noon to me1t $50 \mathrm{kilo-}$ grams of metal. At present, by using an opèn (an iron funnel heated by coke) and aired by a diesel engine (using petroleum, gasoline, and diesel fuel), the metal starts melting within 90 minutes. In a day five tons of metal can be me1ted. Melted metal is poured into tapel (molds) or now also shaped by molding près. In view of the technological requirements of the process, an enterprise there no longer relies solely on human hands and skills but also requires a huge amount of money as capital.

An official of Pabrik Logam Batur, a local government enterprise, explained that private businessmen in the hamlet are extraordinarily successful entrepreneurs. Their capital, labor, production, and markets have expanded continuously. In this small hamlet there are approximately forty-eight enterprises. ${ }^{4}$ The enterprises absorb almost all labor resources in the hamlet. The hamlet has 593 persons (283 males and 315 females) in 217 households. This labor force is supplemented by about 500 laborers who commute here from surrounding villages and by about 200 laborers from Bajat, Semin, and the hilly areas to the south. The latter live in the hamlet on a temporary basis.

An entrepreneur or a merchant goes far and wide looking for basic materials for casting. Coke is sought in gas factories in the cities of Djakarta, Bandung, Semarang, and Surabaja. Efforts are made to find second-hand metal (krèwèng, small junked tools which are cheap, and $l_{i} z_{i}$, big second-hand objects which are expensive, such as pipes and fuel tanks) in villages, towns, factories, and harbors. The entrepreneurs buy up ships, factories, water pipes, cannons, and fuel tanks at auctions, all with complicated calculations and speculations. Their products reach all areas of Java and Sumatra, and some are purchased by foreign merchants. Considerations of profits and losses preoccupy them constantly. Nevertheless, they have chosen the life of the entrepreneur without any hesitation. Although there are thirty-five rice-field owners in the hamlet, they themselves do not work their rice fields. The rice fields are cultivated by hired labor or worked on the basis of fifty-fifty sharecropping.

4. From the "List of the Names of the Entrepreneurs Assigned Compulsory Contributions for Enterprise Permits in 1971 in the Daerah, Desapradja, (Kalurahan) Tegalredjo, Ketjamatan (Subdistrict) Tjeper" (Tegalredjo, September 22, 1970); 22 enterprises from Batur were levied for the contribution. 
The people of Batur were born to live off metal. Usually a village founder's (tjakal bakal) genealogy goes back to a king (radja), but in this hamlet genealogies trace back only to a certain empu (master craftsman). It is said that there were three metal specialists in the kingdom of Madjapahit. Supadali was a tukang pandé (smith), Supadrija an empu, and Supamadurangin a kemasan (goldsmith). The empu Supadrija was a progenitor of Kjai Ageng Bansri or Kjai Ageng Saba (different names for the same legendary figure), who went west to Magetan. A certain Kjai Ageng Serang Kusumo, who also went west with Kjai Ageng Saba, was the one who opened up the territory of Batur. It is said that Kjai Ageng Serang Kusumo possessed kedjèn suro, a harrow which made the land fertile. If carried around the borders of rice fields, this tool protected the fields from misfortune. The kedjèn itself no longer exists, but from its design the Batur people have continued to make kedjèn. Starting from the production of kedjèn, they have produced other tools.

The people of Batur regard themselves as tukang, not as prijaji (officials) or wong tani (farmers). An old man who was once the bekel (tax collector) in the hamlet talked about an incident with a sugar factory caused by the Batur people's unwillingness to work for a sugar plantation because they considered themselves not wong tani but tukang. Neither had they any intention of becoming prijaji to serve the Sunanate (kasunanan) or becoming pegawai (government officials). ${ }^{5}$ It is evident that they want neither to dirty their hands with the mud of rice fields, nor to keep their hands completely clean. What they like is the dirt of tapel and having their hands blackened with charcoal. One can often see an entrepreneur, dressed only in short pants, undershirt, and dirty cap, taking turns with his laborers to throw metal pieces into opèn. The work of these men is that of their old ancestors.

Family and hamlet relationships are very strong. Marriages take place among relatives or in the hamlet. In addressing each other, the Batur people prefix kinship terms to personal names. But the terms have become confused in the course of time, since the genealogies have become increasingly complicated. Until now there have been only two men married outside the hamlet. One married the daughter of a kjai (local Moslem teacher) of a pondok (traditional Moslem boarding school) in Madiun. They stayed in that pondok. Another man has recently married a merchant's daughter in Solo. They, too, live far from the hamlet. The remainder of those who have gone outside the hamlet, however, are those who married among relatives. There are no out-migrants from the hamlet like those in other villages.

Houses in the hamlet stand packed together, without yards, their walls separated only by alleys. All families and, in fact, the entire hamlet are involved in craftwork or industry. Except for the presence of industry, the characteristics of the hamlet are indeed rural. Although it may sound paradoxical, it can be said that industry is the tradition of Batur society. They have been active in

5. Occupations of the inhabitants of Batur are: farmers 28, officials 6 , carpenter 1 , tailor 1 , shopowner 1 , warung owners 10 . The remainder are involved in the metal casting industry as laborers, entrepreneurs, and merchants. 
the field of industry not by going outside the pattern of agricultural economy but by continuing already existent patterns.

Can they liberate themselves from tradition or traditional industry? In fact, what has to be answered here is whether or not there have been any significant changes in their economic attitudes. The success of an enterprise can be seen from increases in wealth, capital, workshop space, labor and production. A Batur enterprise produces things in two ways: for the market and on order. Production for sale on the market, while in larger quantity, means low prices and has the limitations of bargaining and demand. Production on order, although still large in quantity and high in prices, is nevertheless clearly limited. For instance, orders from sugar factories come on $1 y$ after the milling period, that is, when parts of milling tools must be replaced. This work on order does not consume a whole year unless other orders are obtained. So it is apparent that up to now several factors have set limits on the entrepreneurs' efforts, although there have always been ways available to overcome those limitations.

Have there been any actual efforts to surpass those limitations? What is obvious is that these entrepreneurs have already become rich. Larger entrepreneurs now have houses in towns. Such houses do not have any productive value. Their owners stay in them only for vacations, while other days the houses are simply kept ready for use either for themselves or their children who go to school in the towns. In this hamlet there are thirteen private cars, fifty-one motor cycles, and four television sets. ${ }^{6}$ Surprisingly, no trucks or buses are owned by the entrepreneurs themselves, in spite of the fact that trucks must be used for all transportation. There have been no efforts to set up different industrial or commercial enterprises for the increase, extension, and investment of capital. Consumption needs gain importance as a way of acquiring status. It is not that these entrepreneurs do not know money can be used more efficiently. There was an effort in the hamlet to set up a co-operative, Koperasi Prasodjo, but now it is only a name on a sign. More advanced organizational forms to accumulate capital are unknown. The entrepreneurs are satisfied with the production of unfinished products such as irons without handles, coarse legs for sewing machines, bases for weighing scales, unfinished weaving tools. They could certainly accumulate capital to manufacture complete products, but they do not do so. It seems that their wealth is in the state of being but not in that of becoming. Therefore, their demands constitute a fixed need. They are satisfied with particular levels of production and consumption and feel content when they have attained particular levels of wealth.

Religious Attitudes

Batur has a strong santri (strict and pious Moslem) culture. In the hamlet there are three prayer houses (Zanggar) and one

6. Sometimes such houses and possessions are used as security for bank loans. In this respect, they have an economic role. 
mosque. A new, larger mosque with a clinic, a kindergarten, and a meeting hall is going to be built in the southern part of the hamlet. The land used to be rice field but has now been bought by the inhabitants of Batur as wakaf (land donated for religious and community use). It is 4,555 square meters in size. It is apparent that the hamlet is a center of religious activities from the number of youths and adults who teach recitation of formulae (mengadji), give religious lectures (bertjeramah) and sermons (chotbah), and engage in the organization of religious parties. Laborers who commute everyday or stay temporarily to work were at first abangan (syncretic, less or thodox Moslem Javanese), but many of them now have become santri. Those who stay to work temporarily are put up at night at santri employers' houses or even at prayer houses. Outside the hamlet, Batur youths go to visit religious centers in Benda, Tegalșari, Gebang, Tjetan, Krenekan, and Pondokan.

In the 1955 general elections the hamlet was marked as Masjumi (a political party of reformist Moslems). Now the majority is NU (Nahdatul Ulama, a political party of orthodox Moslems) with a minority belonging to Muhammadijah. Almost all entrepreneurs support $\mathrm{NU}$, whose local executive board members are in fact all entrepreneurs.' Muhammadijah is supported by small entrepreneurs and laborers, mostly in the areas of $b$ Zok Zor dalan (the block north of the street), part of kulon dazan (the block west of the street) as well as blok wetan dazan (the block east of the street). According to its head, Muhammadijah has thirty member families, and with Aisjiah (the women's branch of Muhammadijah) the total individual membership is around seventy-five persons. The remainder of the hamlet's inhabitants belong to NU. Their relationship with NU is not that of individual membership but that of en b2oc involvement. NU in the hamlet does not exist as a formal political party but rather as an informal, all-pervasive social group. Between NU and Muhammadijah there are no conflicts. Muhammadijah people in the hamlet go along with NU people in religious and social activities, a feature which does not exist in other villages. The local NU head has stated that their hamlet is a peaceful hamlet. The good relations between Muhammadijah and NU probably derives from kinship relationships and the rural atmosphere.

The support of the entrepreneurs, who aid religious efforts with their economic wealth, has succeeded in promoting religion. In the southern part of the hamlet, there stands amidst rice fields the Madrasah Ibtidaijah Negeri (a government-run primary school), with about 200 pupils in seven classes. The Madrasah was built by the hamlet people and is used in the evening as a private religious school for the fifty pupils of Madrasah Tarbijatul Mubalighin. The two schools are filled with children from Batur as well as from its surrounding areas. Parents in the hamlet seem inclined to send their children to religious schools or schools with religious lessons. There are three university graduates in the hamlet whose academic

7. Participation of entrepreneurs in NU is seen in only a few localities: the kauman (an urban neighborhood of santri concentration) of the town of Purwokerto; the desa of Wonopringgo and Buaran in the district of Pekalongan; the kampung of Djajengan in the city of Solo; the cities of Ponorogo, Kudus, and Surabaja. 
majors in fact reflect the intellectual interests of the Batur inhabitants; they studied religion, economics, and technology, respectively. Those who go to secondary schools enter PGA (six-year government high schools for religious teachers), SMA Muhammadijah (junior high schools), Muslimat (six-year NU high schools), SMA Al-Islam (non-sectarian junior high schools). Most of these schools are in Solo. A somewhat older generation received pondok education in East and Central Java.

Formal education, however, is outside the framework of hamlet life and exerts little influence upon it; and it is religious concerns that are more visible in everyday life. During the fasting month (puasa) there is not a single warung (snack stand) visible in the day time nor young man or adult seen eating on the street. Mosque and prayer houses are always filled with people who come to pray together at shalat hours (the five obligatory daily prayers). In the late afternoon people can be heard praying at places of religious services or in their own houses. Islamic holidays are always accompanied by religious lectures at specified places. Every year a committee is formed to collect the zakat fitrah (a religious tithe due on the last day of the fasting month). In 1970 a total of 2,316 liters of uncooked rice and 200,000 rupiah in cash was collected. The money was distributed for the most part in surrounding villages, for there were few recipients in the hamlet of Batur itself. For the 1970 holiday of sacrifice, Hari Raja Idul Adha (commemorating Abraham's sacrifice), thirteen sheep were slaughtered and distributed. When the need arises preachers are invited from the cities of Klaten, Solo, and Semarang; otherwise other local $\mathrm{kjai}$ officiate at services.

In the hamlet there are fourteen hadji whose names are prefixed with the title of hadji. Every year some families leave for Mecca. In terms of their religious practices, hadji as well as ordinary santri in the hamlet belong to the orthodox group. Their ritual of slametan is filled with the recitation of the Confession of Faith (tahlil), often with the explanation of a request. The latter is intended to make clear the purpose of the slametan and to distinguish it from the abangan type of slametan. Muhammadijah people in the hamlet are not strict purists and do not differ from the majority in religious practices. Reformist divergences, such as shalat ied (prayer meetings held at Hari Raja Idul Fitri and Hari Raja Idul Adha) and not eating at funerals, inevitably arouse conflict in other areas, but they do not exist in this hamlet. The Batur inhabitants' orthodox practices are not due to their affiliation with NU but in fact long predate their NU affiliation. They were urged to participate in NU by their own orthodoxy but not vice versa. NU was established only in 1961 , that is, after Masjumi was banned. Muhammadijah was organized after 1965 and very recently Parmusi (Partai Muslimin Indonesia) was also established.

Social activities are not differentiated; it is difficult to distinguish among hamlet activities, religious activities, and party activities. Examples of mixed activities are: the construction of a 1.5 kilometer road from Tjeper to Batur, which cost 7.5 million rupiah; the construction of Poliklinik Muslimin; the performance of pubiic circumcisions; the construction of schools; the establishment of a community chest (baitul mal); and the construction of prayer houses. The hamlet maintains its identity and 
autonomy in its relationship with the local government and in party politics. Its inhabitants are much more the people of Batur than members of NU, or, as they say, they are much more people of Islam than NU members.

In the day time the hamlet is filled with the sights and sounds of thundering machines and clanging irons, smoke, perspiration, and dirty hands. The evening is quiet with shining electric lights. People stay up late and engage in religious services. The lamps cast 1ights through the darkness of sugarcane and rice fields all night long. In the quietness another life opens up. As the life of reality is in the day, so the world of imagination is at night. God, angel, prophet, and holy spirit, all come close to the hamlet. The inhabitants of Batur describe their life in terms of one of the Prophet's teachings (Hadis Nabi): "Work hard as though your 1 ife in this world lasts eternally. Pray piously as though you are to die on the morrow." 8

Meetings for barzandji (singing of Arabic hymns praising the Prophet) are held by groups of youths, young women, and children. Barzandji is opposed by reformists, for they regard it as bid'ah (heretical innovation), and purists do not agree with its ritual pretensions. Yet, it is apparent that in Batur barzandji receives support from NU members as well as those of Muhammadijah since members of both join the meetings. While the people of Batur are generally poor in cultural expressions, ${ }^{9}$ barzandji songs and poems bring several kinds of satisfaction. First, they assure the continuation of religious traditions. Secondly, their esthetic values give rise to religious values. Thirdly, they are an expression of the collective spirit of the hamlet. Fourthly, they have recreational aspects.

In addition to barzandji, there is samroh (the singing of Arabic songs) by small children. For adult women, there is jasinan, the reading of the Ja-sin text (Surah 36 from the Kor'an). Religious motifs provide the basis of many activities, as at slawatan, where the singing of prayers is accompanied by the djedor (a metai drum with leather heads on both sides) and the gendjrèng (a wooden drum with a leather head on one side). For adult men, there is the gathering of shalawat. Shalawat is a prayer for the Prophet as it is believed that if a person prays once for the Prophet, then the Prophet will pray to God ten times on his behalf. Shalawat is performed at the participants' homes in turns or on invitation. Those who take part prepare drinks and small meals when it is their turn, often with especially good food if the prayer has a special purpose.

Shalawat mundjiah, another type of Arabic prayer is locally known as shalawat tundjina, and is read together at a meeting. The number of times it should be read is not set. Since the reading is not a difficult task, the participants usually total around fortyfive people. Shalawat mundjiah is aimed at preventing oneself from

8. The teaching reads in Arabic: "I'mal lidunyaka kaannaka ta'isu abada, wa i'mal liachiratika kaannaka tamutu ghada." Apparently everybody in the hamlet seems to know the meaning of this teaching.

9. For example, there are no wajang shows or gamelan performances in the hamlet. 
sinning (nadja, to secure safety). It is led by a person in the meeting. There is still another prayer gathering called shalawat närijah (närun, fire) or shalawat kamilah (kamizun, complete), in which a particular shalawat is read. It is aimed at purifying oneself (burning sins), begging pardon in order to attain perfection. If there are not a great many wishes to be presented, the meeting consists of about thirty people. The shalawat nārijah has to be read at the meeting as many as 4,444 times. The responsibility is shared by those who attend.

While the above mentioned meetings are held in a routine way, there are other activities such as manaqib and fida' which happen occasionally. Manaqiblo is performed with the intention of thanking God or requesting God's help and consists of the reading of the story of the founder of the Shadhilijah sect, namely, Sjech Abul Hasan Ali bin Abdullah al-Shadhili (593-656 A.H./1198-1261 A.D.). The reading is often performed in the Arabic language with or without its explanation given beforehand. In front of the reader on top of a table, there are placed sadjèn (ritual offerings) consisting of bread, a cup of coffee, a glass of milk, emas bananas, and sandalwood incense which is kept burning the entire time. It is explained that the sadjèn are only symbols. Only invited guests attend, and they are only expected to 1 isten. Fida' (tebusan, redemption) is aimed at redeeming the soul of a particular deceased person. Fida' is led by a person who divides the readings of the Surah AI Ichlas (112 from the Kor'an) among those present. At the meeting, the text must be read 60,000 times.

On the fifteenth of every Sjawal month (the tenth month of the Arabic calendar) the celebration of chol (chaulun, the year) is held. This is intended to commemorate the founder of the Qadirijah sect, Abdul Qadir a1 Djilani (died in 561 A.H./1166 A.D.). In addition manaqib is also read. Thus chol in the hamlet clearly shows a fusion of Shadhilijah and Qadirijah sects. Its participants state that their sect is open. They come from surrounding villages or even farther as well as from Batur itself.

Individually, the Batur inhabitants also repeat shalat sunah (an extra prayer other than the five obligatory prayers), primarily in the evening. It is said that, according to a certain guru, if an enterprise is established at a place which was previously used for shalat, it will be successful, God willing. If used for planting, the place will be fertile. In the evening, one can often see a person standing to pray in the middle of a yard. The Batur residents also practice wirid (repetition of the name of God and praise for Him).

There is a particular teacher-disciple (guru-murid) relationship in the hamlet. The guru is a kjai who has established a religious sect. Many people in the hamlet belong to the sect of Shadhilijah. The guru gives a series of mystical orders (turkun, djazan) which aims toward self-perfection. A person who wants to take a course in the sect comes to the guru. The teacher first

10. Composed by Yākūt al 'Arshi. See H. A. R. Gibb and J. H. Kramers, Shorter Encyclopaedia of Islam (I thaca: Cornell University Press, 1953), p. 511. 
orders the person to fast for three days. If the person returns and expresses baiat (promise), then the guru gives an instruction (idjazah) of good deeds to be performed. If a person is not strong enough to execute the idjazah, then he should return the assignment to the guru, who will then make a different assignment; otherwise the person would feel unbearable internal pressures. It is surprising to see many entrepreneurs become obedient disciples of this sect. Some of them who do not feel strong enough to bear the discipline of the sect itself take a somewhat easier course.

\section{Conclusion}

The Batur entrepreneurs have already succeeded in obtaining wealth by means of industry; from craftsmen they have become entrepreneurs. Yet there has been no expansion of their occupations into other endeavors. It is as if their work was accepted as their destiny. They believe that the luck (angsar) of the land of Batur is for the industry of metal casting.

The Batur entrepreneurs are bourgeois but of a rural nature. As entrepreneurs they have wealth and power and have become a local business elite. Yet they do not have a capitalist spirit because of certain socio-cultural factors. Moreover, in contrast to the accepted generalization, these bourgeois are not supporters of reform, but, on the contrary, supporters of orthodoxy.

The fixed-need nature of their material demands is a consequence of their way of life, one which longs for harmony between worldly and other-worldly life, between this world and the one hereafter. Anybody who visits the hamlet of Batur would certainly attest to its inhabitants' religiosity. They indeed have coarse hands with peaceful faces. 